\title{
University Teachers: Coping with Sociocultural Diversity. A Study about Critical Incidents between Hegemonic and Subaltern Cultures
}

\author{
Crista Weise, Carles Monereo \\ Universitat Autònoma de Barcelona, Barcelona, Spain \\ Email: crista.weise@uab.cat, carles.monereo@uab.cat
}

How to cite this paper: Weise, C., \& Monereo, C. (2018). University Teachers: Coping with Sociocultural Diversity. A Study about Critical Incidents between Hegemonic and Subaltern Cultures. Creative Education, 9, 959-978.

https://doi.org/10.4236/ce.2018.96071

Received: March 9, 2018

Accepted: May 28, 2018

Published: May 31, 2018

Copyright (c) 2018 by authors and Scientific Research Publishing Inc. This work is licensed under the Creative Commons Attribution International License (CC BY 4.0).

http://creativecommons.org/licenses/by/4.0/

(c) () Open Access

\begin{abstract}
This article aims to identify and characterise the critical incidents (CI) that occur most frequently at university level in highly diverse sociocultural contexts. Intercultural relations will be analysed within the framework of hegemony and resistance between Western culture, which is inherent to university settings, and the non-Western mixed traits present in the student body. The relationship between different CIs will be examined, as will be the various issues associated with them according to teachers' perceptions. For this qualitative study, 23 teachers from two Bolivian universities were interviewed. The teachers reported 9 types of CIs linked to sociocultural diversity. The results indicate that CIs are usually the outcome of cultural clashes between the institutional and teachers' culture and the students' culture, with the three most frequent CIs related to the use of the vehicular language, expression and communication; different thinking processes and the relationship between students. As a result, we propose a typology and a scheme for classification and interpretation of CIs linked to cultural diversity with the objective of advancing university teacher training.
\end{abstract}

\section{Keywords}

Intercultural Relations, Cultural Diversity, Critical Incidents, Teacher Training, University, Bolivia

\section{Introduction}

Cultural diversity is highly relevant today both in Western countries and in Latin America, although admittedly for different reasons and with different nuances. 
Linked to the immigration issue faced in Europe, intercultural projects there are usually questioned. Many people are quick to announce the failure of integration policies; whilst others revive extremist, and even racist, discourses. Meanwhile, educational settings witness increasing diversity in their classrooms and the debate rages on about what aspects of immigrant cultures should be respected and which ones should be rejected ${ }^{1}$.

In South America, there is increasing awareness of indigenous issues and progressive transformation of government structures, a situation which undoubtedly poses new challenges for educational systems. This situation results in two interesting phenomena: on the one hand, an increased presence in educational settings of formerly marginalised communities (those from rural areas, indigenous background and/or those who had previously been socially excluded), and on the other, the prevalence of alternative discourses based on cultural acknowledgment (Bauer, 2015; Centellas, 2015).

This situation is particularly complex in the university context, whose institutional backbone is composed of the epistemological principles from Western science. Universities are secular institutions that maintain as their core function of the production and reproduction of knowledge, thought to be of a higher order (Mollis, 2003) due to its scientific basis. These premises are now being questioned by emergent indigenist discourses.

Such discourses have been highlighting the need to recognise and incorporate indigenous knowledge into university education, to foster intra and intercultural education, which is decolonising and plural (Ley de Educacion Boliviana ${ }^{2}$ No. 070 de diciembre de 2010, Matto, 2009, 2010). Nevertheless, aside from the media debate they have sparked, these discourses have not made their mark on research about the problems and challenges faced by university teachers in their daily practice with students of diverse cultural background (mestizos, indigenous Quechua, Aymara and Guarani) (Lopes Cardozo, 2012).

This research aims to answer questions such as: what are the most frequent and emergent problems faced in university contexts with high sociocultural diversity? How do teachers define such problems? Are they isolated issues, or are they interrelated?

In order to answer these questions, we intend to: a) identify and characterise the critical incidents (CIs) that occur most frequently in university contexts with high socio-cultural diversity; b) describe the relationships between these CIs, and c) analyse what issues teachers believe are usually linked to these CIs.

Such information will allows us to gain better understanding of concrete manifestations of the relationship between cultures inside the classroom and of

\footnotetext{
${ }^{1}$ Studies looking at enrolment growth in Spain since 1997-1998 show a marked increase in immigrant population. In 2004 immigrants represented 5.65\% of students at non-university level, which means that out of the total $6,895,880$ students, 389,726 were immigrant. In primary and secondary education, in specific, immigrants represented a $6.96 \%$ and $5.78 \%$ respectively, according to official data from the Ministry for Education \& Sciences, MEC (Ministerio de Educacion y Ciencia, Centro de Investigacion y Documentacion Educativa, 2009).

${ }^{2}$ Bolivian Education Act of 2010.
} 
the resulting needs for improved teacher training.

For this study, we decided to examine two universities in Bolivia, given that this country is a paradigm in terms of high number of indigenous peoples at university and the increasing demand for greater acknowledgment and attention to cultural diversity at university level.

We believe that our study results will prove a useful contribution to the reflection on the attention given to sociocultural diversity and teacher training, not only in countries with indigenous population but also those with immigrant population, who are all increasingly being assimilated into their educational systems.

\section{Theory}

\section{Education and cultural diversity}

The debate on education and sociocultural diversity has been encapsulated within the framework of intercultural education.

Muñoz Sedano (2001) distinguishes four major approaches to intercultural and multicultural education: 1) as an affirmation of the host country's culture, 2) as a prospect for the integration of cultures (Berry, 2001), 3) as an approach to acknowledge plurality and 4) as an approach to cultural asymmetry (Grosfoguel, 2006; Ogbu, 1994; Quijano, 1999).

It is the last approach that we have chosen as the basis of our study, given that in Bolivian diverse local cultures have had an asymmetric relationship due to central opposition between native (non-Western) and Western cultures.

Contrary to what happens within the European debate, where asymmetry is defined by the presence of a host culture and a series of immigrant cultures, in Bolivian universities there are various native cultures together with communities of mainly Western cultural traits, and the relationship between them has developed in the dynamics of hegemony and resistance (Weise, 2009).

The roots of such dynamics can be traced back 500 years to the colonisation of indigenous people, a situation which can only be understood by making a socio-historic and political review of the relationships between cultures and their participation in the educational system. Social class and race are interrelated factors and various studies show a regressive correlation between belonging to native or black cultures and access to education in Latin America (Telles, Flores, \& Urrea-Giraldo, 2015; Fontana, 2014).

From this perspective, interculturalism is not an ideal to aim for; it is rather a historical and social reality which does not necessarily have a positive connotation. Its analysis reveal tensions and power relations between hegemonic and subaltern cultures who interact with each other, but at the same time, there is a dispute for hegemony in social spaces, and in the educational space in particular (Carnoy \& Levin, 1985).

Intercultural relations are grounded on social structures and institutions that promote domination and reproduce contradictions, and schools and university 
are obviously part of them.

This asymmetric relation between cultures may give rise to various processes of assimilation (a subaltern culture loses its identity by integrating into another), invisibilization of one or various cultures (those that survive underground, who are apparently assimilated into the dominant culture, but who keep their identity traits whilst cohabiting with the dominant culture) o "desubalternization" (Grosfoguel, 2005; Mignolo, 2000), that is, an emergency response to subalternization through which communities gain visibility, power and symbolic value in a given society.

Bolivia has transitioned from an invisibilization process of native cultures towards gradual acknowledgement and empowerment, where "indigenous matters" now occupy centre stage in national policies (Svampa, 2010; Svampa \& Stefanoni, 2007; Tapia, 2008).

The educational setting is not neutral; it is rather a conflict arena in which the hegemonic culture exerts symbolic violence over subaltern cultures via the curriculum, educational rites, school norms or institutional values. There is an implicit struggle in the dichotomy power/knowledge, which was extensively analysed by structuralist and post-structuralist theoreticians (Bernstein, 1994; Foucault, 1992) and which depicts educational settings as a symbolic battle ground, in which is clearly dominated by codes, contents, control systems, discourses, construction of truths and rationality that take shape in educational practices (Bruner, 1991).

Identifying and examining CIs through the analysis of university teaching practices will be a valuable approach to this dynamic and complex reality, given that one of the key features of using CIs is the possibility it affords of looking into practical matters and situated performances, thus allowing us to identify the characteristics and conditions in a given context.

\section{The Critical Incident Method}

A CI is a situation that draws our attention, an event that causes certain dissonance, that makes us feel uncomfortable or that forces us to deliver an unplanned performance (Monereo, Badia, Bilbao, Cerrato, \& Weise, 2009).

In the educational context, we understand a $\mathrm{CI}$ to be an event that causes a crisis or destabilises the teacher's action, crossing an emotional threshold as a consequence of a dissonance between an emergent situation and the teacher's original intentions.

CIs are concrete events, situated in time and space. They are context-bound but in some occasions they are indicative of deeper underlying problems or conflicts (Burgum \& Bridge, 1997). They are not simply the trigger to a given situation but they are rather rooted in latent conflicts which at given times become manifest under the guise of critical incidents.

For example, a CI related to a student's misbehaviour may be rooted in the student's maladaptation to the school, or it could be a manifestation of resistance to school culture, to discriminatory situations, etc. 
During a CI there is a succession of activities, processes and decisions; multiple tools and transactions intervene and there are different timings and types of response by the actors involved. There are also diverse results and consequences. Analysing CIs is a qualitative and phenomenological method which allows the actors involved to reflect on their experiences, behaviour and feelings (Malpass \& Salancik, 1977).

Although there are different approaches and methods for the analysis for CIs (Burnard, 2005; Cohen-Emerique, 1999; Monereo, 2010; Navarro, Lopez, \& Barroso, 1998), most authors agree that the analysis of a CI involves taking into account: the antecedents to the event, the unfolding of the CI and its possible interpretation and/or re-description.

CI events take place in a wide range of fields, which is why we come across various typologies in relation to different aspects of educational practice. In general terms, we have found at least four types of CIs (Navarro et al., 1998):

- Didactic incidents (planning, use of methods, contents, use of time, assessment, learning results, etc.)

- Organisational incidents (of an institutional nature or at class level)

- Incidents related to in-class supports and negotiation (teacher-student interaction)

- Incidents related to sense and sensibility (meaning of actions and affective or interrelation issues)

This classification, however, does not consider the socio-cultural variable.

The literature on conflicts arising from sociocultural diversity tends to situate CIs in primary or secondary educational contexts (Angelides, 2001; Castagno \& Brayboy, 2008; Haas, 2006). Furthermore, they focus on relationships between local cultures and immigrant cultures (Maya-Jariego, 2010), cultures from different countries which coincide in transitory events such as study visits (Addleman, Nava, Ceballos, Brazo, \& Dixon, 2014) or on the repatriation of immigrants who reinsert themselves in their own culture after spending some time abroad (Arthur, 2000; Ford, 2009).

Studies specifically focused on contexts with hegemonic relationships between local cultures of diverse backgrounds (indigenous and non-indigenous cultures, western and non-western cultures) are rather scarce.

We did find research studies that at a macro level analysed intercultural incidents arising among social groups and movements as a result of difficulties negotiating interests and generating consent (Ramos-Vidal, 2011). These studies have also highlighted the value of analysing CIs in culturally diverse contexts, stressing their validity as a method to identify the different emotions generated in intercultural communication and the effects said emotions have on the development of intercultural contacts (Snow, 2015).

In this regard, CIs have been considered an effective tool in the analysis of intercultural situations in which the subjects have been involved (Cohen-Emerique, 1999). Similarly, they have proved suitable for use in training to face culturally 
diverse environments, such as that given to expatriate workers or students who must pursue education in a country different to their home country (Arthur, 2001; Brislin, 1986; Cohen-Enrique, 1999; Malpass \& Salancik, 1977).

In general terms, this type of incidents can be classified as follows:

1) Incidents related to interpersonal relationships between students in instances of discrimination (Vazques-Bronfman, 1996).

2) Incidents related to social exclusion and group belonging, such as instances of bullying and victimisation (Murakami, 1985).

3) Incidents related to the type of interactions, the nature of classroom communication and the level of class participation. Along the same lines, Vázquez Aguado (2002) pinpoints communication as the first obstacle in intercultural relations. Also agreeing with this assessment are studies on the role played by language in intercultural conflicts (Ladegaard \& Jenks, 2015). These conflicts are associated with misunderstandings due to insufficient command of language at its different production stages (semantic, pragmatic, morpho-syntactic and/or discursive)

4) Different world views or difficulties understanding others' viewpoints.

Complementing this classification, Ramos-Vidal (2011) attributes the causes of the main intercultural incidents to clashes due to:

a) Different perceptions of time and space.

b) Differences in the family structure: type of family, kinship system, male and female roles, modes of communication among family members, modes of social control and children's socialisation.

c) Different types of sociability: hospitality, interpersonal exchanges, coexistence norms.

d) Types of demands for help that immigrants make to professionals.

e) Confronting rites and beliefs associated to a person's milestone events in life, from birth till death.

f) Prejudices and stereotypes linked to such cultural differences.

This study will identify the main CIs occurring at two highly socio-culturally diverse universities and will propose a specific CI classification, based on empirical data reported by teachers, which will enable us to identify potential conflicts. Such classification aims to overcome the solely pedagogic/didactic approach to the CIs studied in the educational field, by incorporating the sociocultural variable in their analysis and situating them in the university context.

\section{Methodology}

The research took place in two Bolivian universities, one of which is public and the other one private. The voluntary participants were 23 university teachers, most of whom worked in social sciences (17) and the rest in engineering (5). They all averaged 5 years of teaching experience and their age ranged from 35 to 45 years.

The unit of analysis was the statements extracted from the teacher's own account of their teaching performance: how they described their experiences, how 
they interpreted them and how they felt whilst the CIs unfolded.

In order to collect the data, a semi-structured interview was performed within a framework of $\mathrm{CI}$ analysis, in which the teachers recounted the CI, the antecedents to it, the event itself and their interpretation of it. In the next stage, a second interview took place in order to delve into or complement the key details that were identified during the initial coding of the information.

Reliability of qualitative research is understood as the degree to which the answers given are independent of the accidental circumstances of the research, and validity refers to the extent to which such information is interpreted correctly (Barab \& Squire, 2004; Geertz, 1983). In order to ensure the reliability and validity of our data, we have observed the requirements highlighted by Geertz (1983) and LeCompte, Preissle and Tesch (1983): the researcher's status, participant selection, analytical premises and constructs, collection methods and data analysis.

In order to process the statements collected, the Atlas.Ti 5.0 programme was used. A general, basic theoretical framework provided the main categories used in the interview and from then onwards a combined codification strategy was employed: bottom-up codification following the guidelines from grounded theory (Corbin \& Strauss, 1990) and top-down codification.

In the first instance (top-down codification), we used the categories that were included in the interview and which refer to the dimensions related to the socio-culturally diverse nature of the teachers' daily practice contexts. The bottom-up codification was then performed and from the analysis of the information gathered we were able to identify emergent categories. The main criterion used for clipping the statements was the beginning and end of a complete idea expressed by the teachers.

From this double codification we were able to put together an operational chart, through which the information was processed and analysed, establishing a link between the different levels of codification.

We then proceeded with an expert validation of the proposal for codification and classification of the CIs identified in the first stage. The 16 experts all belonged to the same universities as the participants and the validation was performed through a face-to-face workshop and a virtual validation questionnaire, in the underjudge's modality.

For the analysis we followed the procedure proposed by Miles \& Huberman (1984), which consists of analysing the interview transcripts over several phases. First, we performed a vertical and horizontal analysis of the data so as to create semantic families and networks in the data (co-occurrences and nearest neighbours). We then proceeded to analyse the results using the specific segments and references from the data that were expressed in over 30 semantic networks.

\section{Results}

Our first aim was to identify and characterise the CIs that occur most frequently 
within university contexts with high socio-cultural diversity.

Having analysed the mentions (=117), we created emergent categories and codified the CIs, identifying what central topic each incident account had to do with. We organised the set of situations described by the teachers around the central topic they were referring to and identified nine types of CIs. Similarly, we analysed the semantic weighting of each of the statements in the teacher' accounts and recorded the frequency of mention.

For each type of CI we only presented examples that were illustrative of the typology each refers to and that achieved a clear consensus among the judges.

As can be seen, the incidents that the interviewees cited more frequently were those related to language, expression and communication (1) and those related to attainment (2). 11 out of the 25 interviewees mentioned this latter type of CI and this was clearly seen as an important factor in all the interviews.

CI Type 1 (language, expression and communication) encompasses episodes arising from insufficient command of the vehicular language used at university, its academic use, oral and written expression and, in general, the use of language as a tool for communication and construction of knowledge.

Here are some examples of the sort of issues the teachers reported:

"There is a high number of students of peasant background or who come from popular urban classes, who do not speak Spanish fluently, and thus they have problems with comprehension and with oral and written expression, which in Social Sciences is a distinct disadvantage. I had a long list of complaints where students mentioned problems understanding the texts in the reading lists associated to the classes."

"This happens frequently, nobody should mock someone who has some difficulty expressing themselves at times, but they do mock them. This doesn't mean that they do not know what they are talking about, because people do understand, but they cannot express it verbally.

Table 1. CI Number of mention.

\begin{tabular}{lcc}
\hline \multicolumn{1}{c}{ Incident } & No. Interviews & No. Mentions \\
\hline 1) Language, expression, communication & 11 & 25 \\
2) Attainment & 11 & 19 \\
3) Reasoning & 9 & 21 \\
4) Relationship between students & 7 & 14 \\
5) Contextualisation & 5 & 6 \\
6) Educational background & 5 & 11 \\
7) Relationship between teacher and students & 4 & 7 \\
8) Evaluation & 4 & 3 \\
9) Pace & 3 & 11 \\
\hline
\end{tabular}

Table 1 is done with Atlas.Ti based on the interviews. 
"These problems with expression are usually attributed to language, but I don't think they are due to language but rather they have to do with mental structures that are expressed through language, so it's not that they cannot understand what words mean (...) This girl didn't have the tools to express her thoughts. She tried explaining herself in Aymara, but then she said: no, it s not like that in Aymara, but this is not because of language, it is because of logic. She can understand, no doubt about it (...) she has a good grasp of Spanish, but what happens is that she doesn't have the logical tools, she lacks structure in her academic language to be able to express herself."

CI Type 2 (attainment) is in turn associates the students' sociocultural diversity with low attainment, low results in assessments, fail marks, attrition, desertion or a low academic level in general, where students do not achieve the attainment levels or the results expected by their teacher.

Here is an example:

"For instance, today I will set an exam in a module that I love teaching, and sometimes I feel I lose focus. I have noticed that sometimes I think the exam I ve written will be fine for the students, I think it's simple, and I make sure to design a very easy exam because I feel as though they are not following me. There have been times when I have asked questions and they were not following me. So I tend to believe P ve written a good exam paper but then when I start marking them I pull my hair because I was wrong, they haven't understood the exam, so I question myself and think that there is a common problem right there, especially with some classes. The attainment level is low."

In the second and third place are those incidents related to different thinking processes (3) which are in turn the ones that appear in a greater number of mentions as a whole, and those related to situations of student interaction (4).

IC Type 3 (thinking processes) refers to the CIs in which teachers acknowledge difficulties arising from their own lack of understanding and from having made insufficient adjustments and modifications to their modules so as to accommodate different ways of learning, reasoning, knowing about or viewing the world, which differ from the teacher's own culture and/or the culture where the educational process is set.

"Something we usually have some problems with is the matter of understanding the concept of time and managing it. People from the countryside have a different notion of time. At the university we work at a different pace, we have deadlines and this timeframe is not flexible, there are deadlines to meet and I think this causes a clash with the experiences and viewpoints of non-Western cultures."

"One of the problems is ordering the logic of knowledge on their part."

"It's a matter of learning concepts, it's a different logic. An Aymara's mental schema is different to that of a Guarani or an Easterner or a Quechua even, right? This poses a problem, but that's what it is, a different mental schema."

CI Type 4 (relationships between students) has to do with interpersonal con- 
flicts, offensive remarks, physical or verbal aggression or discriminatory attitudes among students of different sociocultural backgrounds.

"There was this girl with very native features, with a very typical autochthonous look. She was dark-skinned, thin, and she was not being accepted by the group. This is something that happens frequently, they are excluded from group activities.

"I had this Aymara girl with a braid, she was wearing jeans and everything but she still kept her braid and her hair, and I remember when I saw her. She was sitting at the front, I was asking students for their opinion on a topic and she raised her hand. She kept her hand raised but her classmates started to laugh, they were laughing and mocking her because she obviously had Aymara features and also because of the way she talked, she had an accent, I got angry."

Less frequent are incidents to do with contextualisation of content CI (5) and those related to students' educational background CI (6). Finally, we have those incidents linked to assessment CI (8), to the relationship between teachers and students CI (7) and to learning pace CI (9).

CI Type 5 (contextualisation) includes those problematic situations reported by the teacher which relate to insufficient contextualisation of content, to the use of cultural referents which are alien to the students' socio-cultural background, to the difficulties in situating content or linking it to the students' native culture.

"whenever I talk to my students I have this strong feeling that what they experience at university is something quite disjointed, disconnected, which is at odds with what they have experienced in life and education."

"we chose an example from chess to liven up a mathematical problem in an exam, then we noticed that many students failed to answer the question correctly and so we realised that many students didn't know about chess and most had never played it before."

For its part, CI type 8 (assessment) encompasses problems related to insufficient adaptation of assessment procedures to the students' sociocultural profiles or to those problems arising at the time of assessment, which are usually a result of any of the other types of incidents.

CI type 6 (educational background) has to do with situations in which the trigger is the students' educational background. These CIs relate to the identification of deficiencies or shortages in schooling and a poor selection process for admission to university.

Finally, CI type 7 (teacher-student relationship) encompasses conflicts or destabilising situations resulting from clashes or difficult relationships between teachers and students due to socio-cultural traits displayed by one or both parties in the educational process.

"the problem I had was getting everyone's attention, for example, and so I had to raise my voice even more and sometimes this didn't work, and in fact, I always feared I might be too harsh and still not have an effect, as this would have been a disaster." 
CI type 9 (pace) refers to incidents related to learning pace, the time spent for the development of academic activities, the need for longer time to complete tasks, the lack of punctuality and delays in submitting work.

In terms of frequency of mention, the incidents which are clearly more relevant are those linked to language, expression, communication; attainment; thinking processes, relationship between students and contextualisation of content.

\section{Relationship between critical incidents}

Our second objective was to identify and describe the different relationships between critical incidents.

From the analysis of co-occurrences and nearest-neighbours via Atlas ti, we observed that CIs are not isolated events but they are instead linked to other destabilising situations which potentially trigger CIs. We identified relationship patterns that enabled us to establish associations between the different types of CIs.

From the information gathered, we were able to observe that when a reference is made to a type of CI, this is usually pinned to others or is highlighted as the likely cause of others.

We formed semantic networks by analysing the relationships between the different types of CIs and identified relationship nodes, as well as the explicit association of the CIs with the sociocultural dimension.

A node is understood as an intersection point where various elements in the network converge and which connects types of CIs which have an influential or recursive relationship between them. In this regard we can distinguish between primary CIs and secondary CIs.

Primary CIs are those which are clearly situated in the sociocultural axis (nodes 1 and 2). They are a type of conflict which arises from the students' sociocultural traits. In turn, those in Node 3 are secondary incidents which are reported as a cause or a consequence of those in nodes 1 and 2 and there is no indication in the interpretation made by the teachers participating in our study.

Figure 1 shows what incidents are interrelated. We notice there are groups in which different types of incidents converge, making up three nodes in the network.

The first node, in the map's lower left corner, shows the links between incidents to do with discrimination, relationships between teacher-student, student-student and language and expression, marking an interrelationship node (node 1). The second node appears in the right-hand side of the map, and it is where conceptions of culture, contextualisation of content and learning pace are linked (node 2). Finally, in the upper part of the map, we can see the association between assessment, attainment and educational background (node 3 ).

The CIs making up node 3, which are linked to attainment, assessment and educational background, have a bearing on the others. That is to say, not only were they reported by the teachers in conjunction with others, but they were also 


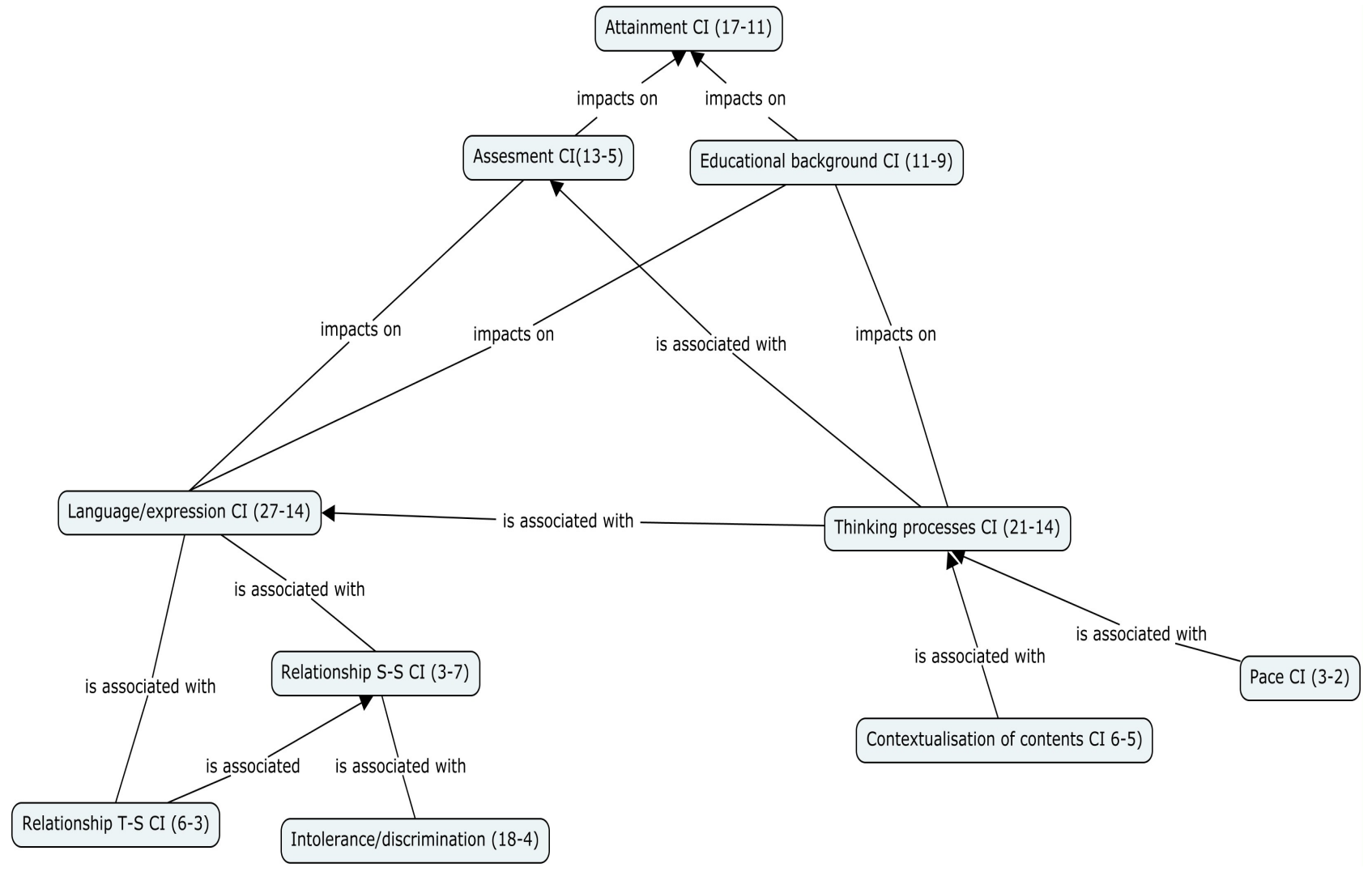

Figure 1. Map of CI relationships: nodes.

pinpointed as directly related to the others, either as their cause or a consequence, although they are not directly linked to sociocultural diversity.

Thus, CIs linked to assessment are rather a consequence of one or more of the previously mentioned incidents. CIs linked to attainment also appear to be a consequence of nodes 1 and 2 .

In relation to this, the teachers made statements such as:

"What happens later is that, as they can't understand Spanish, the assessment reveals the problem..."

"Their previous schooling is the problem; they come from substandard schools, that's why they cannot perform."

As a third objective, we aimed to describe what issues-from the teachers' perspectives-are linked to these CIs.

For that purpose, we analysed the content of the mentions in depth. A more detailed analysis showed the relationships between the different CI types and the issues linked to them (Figure 2).

We posit that CI type "contextualisation of content" is linked to the issue of different cultural referents, which hinders the students' ability to relate the school content to their own cultural references. Teachers plan and develop class content based on their own schema, ignoring cultural differences, thus resulting in decontextualized activities which are far removed from the students' realities and which may be masked as attainment issues when in fact they are the result of 


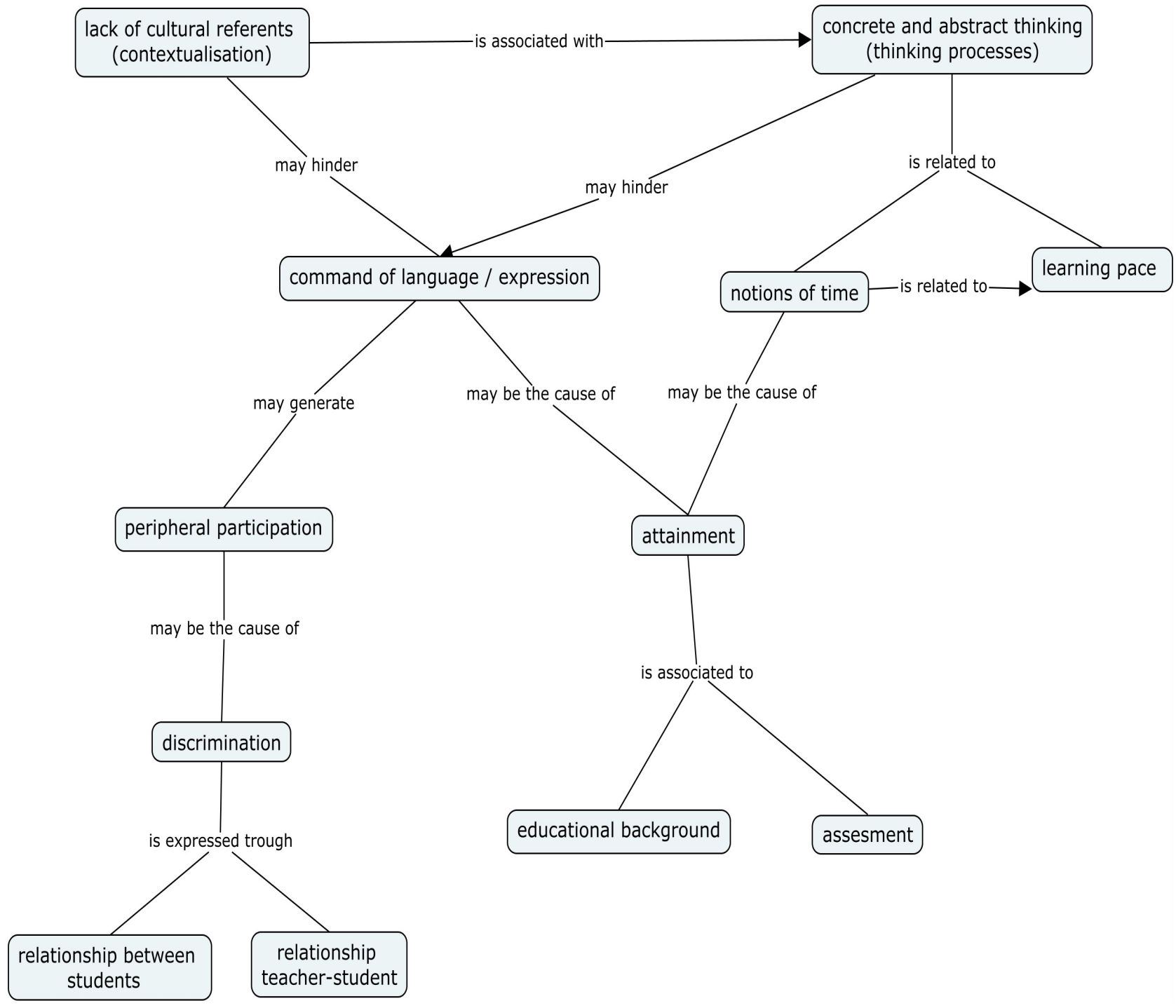

Figure 2. Map of CI interpretation.

a clash of cultural referents that are erroneously considered to be shared.

This CI type is in turn linked to thinking processes CIs, which have to do with two main problems reported by teachers: the relationship between "concrete and abstract thinking" and "notions of time", which is linked to the students' learning pace.

Teachers feel that in addition to all the difficulties faced in understanding the students' context, there are deeper problems linked to different thinking processes, which many believe are due to difficulties to access "abstract thinking", an essential skill in university studies and for accessing scientific knowledge.

Similarly, the teachers acknowledge that one of the most important issues that surface in class are the students' different notions of time, which often clash with the institutional culture, and the demands placed by formal university learning.

In the interviews, teachers linked both contextualisation of content CIs and thinking processes CIs to those to do with language, expression and communi- 
cation.

Difficulties with language, expression and communication have to do with insufficient command of the vehicular language (Spanish) and particularly with problems handling the codes and cultural tools inherent to university education.

Teachers report that even if indigenous students or those from rural areas speak and write correctly in Spanish, they still have difficulties constructing thoughts with this language (whether in the spoken or written forms). Studies carried out in Bolivia confirm the uses of Spanish-Quechua as a linguistic variant of a highly contextual and variable use depending on the nature of interaction between subjects and their social background (Babel, 2014; Hornberger \& Swinehart, 2012). Thus we find a direct correlation with thinking processes, given that the use of language is built upon sociocultural patterns.

Such difficulties with language, expression and communication in turn lead to situations of peripheral participation (Wenger, 2000) which manifests itself through self-isolation, peer margination, invisibility, limited participation, etc. This may even lead to discriminatory situations with subsequent conflicts in interpersonal relations between the actors involved in the educational process.

In this framework, assessment and attainment CIs are the result of conflicts caused by insufficient adjustment to sociocultural diversity. Educational background is an added factor which is linked to social conditions, given that rural education is deficient and not very well adapted from a sociocultural point of view.

\section{Discussion}

The literature on intercultural critical incidents in educational settings mainly centres on analysing interpersonal conflicts in the classroom. Such studies view interculturalism from the perspective of instilling values, resolving conflicts or teaching languages in bilingual settings (Freeland, 2003). However, there is little research on the component features of different cultural models that coexist in the same institutionalised formative environment-such as schools and universities and which clash or have to negotiate with each other in a process of adaptation and appropriation of the resources in that setting.

Analysing the CIs enabled us to evidence how different action schemes, procedures or sociocultural guidelines take new shape in the university context, which are not always noticed by teachers and students but do trigger destabilising situations.

Our analysis showed that conflicts take place at different levels as the result of clashes between cultural features that are difficult to reconcile: those of the institution and its disciplinary norms, those of the teachers and those of the students from a non-Western cultural background.

For each of the CIs, we were able to distinguish a structural dimension manifesting hegemonic and dominant relationships between cultures. Favouring certain forms of thought, discourses and practices over others are inextricably 
linked to the origin and nature of the conflict.

Thus, conflicts are not caused by the presence of two or more cultural views, but they are rather the result of their unequal footing, which hinders the reconciliation of views and practices in the university context.

The most frequent manifestations of this cultural clash are usually categorised into the four blocks suggested by Ramos-Vidal (2011), as mentioned in our introduction (relationship between students, social exclusion and sense of group belonging; communication in the classroom, different world views).

In general, our findings coincide with results from previous studies. But the classification presented in our introduction focuses on the students and does not clearly reflect the notion of cultural clash that we posit in our study. Taking the results as a starting point, we widened and completed the classification, as shown in Table 2.

Table 2. Classification of critical incidents.

\begin{tabular}{|c|c|c|c|}
\hline Initial Classification & Assessment & Proposed Classification & Associated issues \\
\hline $\begin{array}{l}\text { 1) Incidents related } \\
\text { to interpersonal } \\
\text { relations between } \\
\text { students }\end{array}$ & $\begin{array}{l}\text { It does not include interpersonal } \\
\text { relations between teachers and students. } \\
\text { It does not include discrimination as an } \\
\text { issue arising from unequal relationships } \\
\text { between cultures. }\end{array}$ & $\begin{array}{l}\text { Incidents related to discrimination and } \\
\text { interpersonal relationships between } \\
\text { students. (CI Type } 4 \text { ) } \\
\text { Incidents related to discrimination and } \\
\text { interpersonal relationships between } \\
\text { students and teachers. (CI Type 7) }\end{array}$ & $\begin{array}{l}\text { - Discrimination } \\
\text { - Intolerance } \\
\text { - Interpersonal } \\
\text { communication } \\
\text { - Prejudice } \\
\text { - Peripheral Participation }\end{array}$ \\
\hline $\begin{array}{l}\text { 2) Situations to do } \\
\text { with social exclusion } \\
\text { and group belonging }\end{array}$ & $\begin{array}{l}\text { Social exclusion can be the result of } \\
\text { other factors such as interpersonal } \\
\text { relationships in the classroom, or } \\
\text { discrimination. Group belonging is a } \\
\text { subjective element. }\end{array}$ & $\begin{array}{l}\text { These are merged with the interpersonal } \\
\text { relationships and discrimination CIs. }\end{array}$ & \\
\hline $\begin{array}{l}\text { 3) Problems to do } \\
\text { with classroom } \\
\text { communication }\end{array}$ & $\begin{array}{l}\text { This also refers to interpersonal } \\
\text { relationships, but is linked to the use of } \\
\text { language. We believe the problem has } \\
\text { more to do with appropriation of } \\
\text { cultural tools characteristic of the } \\
\text { university context, the vehicular } \\
\text { language among them, and so it is not a } \\
\text { matter of interpersonal relationships as } \\
\text { such but the use of said language in the } \\
\text { learning requirements. }\end{array}$ & $\begin{array}{l}\text { We propose: use of language, expression } \\
\text { and communication. (CI Type 1) }\end{array}$ & $\begin{array}{l}\text { - Insufficient command of } \\
\text { the vehicular language } \\
\text { - Use of language as a tool } \\
\text { for communication and } \\
\text { production of knowledge }\end{array}$ \\
\hline \multirow[t]{2}{*}{$\begin{array}{l}\text { 4) Different world } \\
\text { views }\end{array}$} & $\begin{array}{l}\text { Different world views are the wider } \\
\text { cause of the problem, not its } \\
\text { manifestation. We believe that different } \\
\text { world views clash with each other and } \\
\text { become manifest in concrete } \\
\text { circumstances. }\end{array}$ & $\begin{array}{l}\text { We propose: CI: Reasoning (CI Type 3) } \\
\text { CI: Contextualisation of content (CI } \\
\text { Type 5) } \\
\text { CI: Learning Pace } \\
\text { (CI Type 9) }\end{array}$ & $\begin{array}{l}\text { - Different underlying } \\
\text { forms of reasoning in } \\
\text { thought processes } \\
\text { - Notions of time } \\
\text { - Insufficient consideration } \\
\text { of cultural referents }\end{array}$ \\
\hline & $\begin{array}{l}\text { The teachers mention other types of CIs } \\
\text { that do not fit in the initial } \\
\text { classification. These are secondary, as } \\
\text { they are either the cause or the } \\
\text { consequence of the others. }\end{array}$ & $\begin{array}{l}\text { CI Educational Background (CI Type 6) } \\
\text { CI. Evaluation (CI Type 8) } \\
\text { CI. Attainment (CI Type 2) }\end{array}$ & $\begin{array}{l}\text { - Deficient education } \\
\text { - Ill-adjusted evaluation } \\
\text { - Low attainment }\end{array}$ \\
\hline
\end{tabular}


One of our main findings is that CIs do not happen in isolation. Teachers put forward a number of interrelated concerns which gave us a good snapshot of the sociocultural issues that become entwined in university classrooms. CIs are like onion layers: some CIs are superimposed upon deeper CIs.

Not all sociocultural incidents take place with the same degree of intensity or in the same manner. There are incidents of a more structured and deeper nature which appear in a veiled manner, whilst other elements of cultural diversity are more superficial and evident.

CIs related to thinking processes and notion of time are deeper layers, whilst CIs linked to language and expression are more evident, although as the latter are directly linked to thinking processes they also have important underlying components. The CIs situated in the axis content contextualisation, discrimination and participation are outer layers, at a more explicit and superficial level, and are therefore more visible to teachers.

It is worth mentioning that identifying CIs and their causes is an extremely complex endeavour in culturally diverse contexts of a hybrid and mixed nature which resulted from involuntary enculturation processes (Ogbu, 1994) that have been ongoing for a long time (such as the Bolivian case). This is because both teachers and students keep traits from both cultures (Western culture and any indigenous culture) (Hornberger, 2014). They have gone through an extensive process of appropriation of Western cultural tools and have internalised values and schemas from both cultures, which necessarily creates contradictions. We are not talking about binary oppositions between clearly defined cultural identities but about cultural traits-both Western and non-Western, which clash with each other but only in certain educational circumstances.

It is also worth pointing out that, as evidenced by our study results, CIs are multifactorial and are not caused solely by sociocultural diversity. However, this dimension must still be stressed or otherwise critical incidents run the danger of being addressed as purely instructional or didactic issues, or as mere attainment-related problems.

Our analysis enable us to maintain that fostering educational processes at university level that are culturally relevant and strive for more balanced intercultural relations will necessarily involve making profound changes, which will imply questioning the existing rationales and discourses in the university context that currently inform teaching practices.

This would also entail adopting a plural view of culture, thought and knowledge. The work done so far towards including certain "intercultural" contents or instilling values to foster more symmetrical cultural relations is certainly commendable but clearly insufficient.

In this endeavour, the teachers are the key players, and thus it is imperative that they are involved in the design of teaching strategies and initiatives for better addressing sociocultural diversity and that their experience, systematic reflection on CIs and their attainment in daily teaching practice are also taken into 
account.

Whilst many of the CI causes are structural and thus beyond their power, teachers must still be able to acknowledge and understand the problems, take them into account in their class planning and development and put into evidence the representations and emotions impinging on their practice, thus being able of regulating their performance.

\section{Conclusion}

Although there is a wide range of potential CIs, it is still possible to identify, classify and define specific CIs which occur most frequently in highly diverse sociocultural educational contexts and which are linked to the issues characteristic of this type of context.

Among the nine types of CIs that we identified-language, expression and communication; thinking processes; notion of time; contextualisation of content; relationship between teachers and students, and between students themselves and discrimination, participation, assessment and attainment, it was possible to distinguish primary CIs and secondary CIs, according to the weighting they take in relation to the sociocultural dimension.

The CIs in highly diverse sociocultural contexts are multifactorial manifestations and they are linked to a clash between traits of the students' native culture and that of the teachers', to the epistemological nature of the institution and its type of teachings, within a framework of asymmetric power relations between these cultures.

Producing a classification and interpretation scheme for CIs linked to cultural diversity is a significant contribution towards improving teacher training, as giving visibility to the CIs' sociocultural component and also identifying the issues associated with them will undoubtedly help promote more suitable formative actions.

Notwithstanding our research results confirm the presence of different world views, we still have a very limited understanding of how students learn in multiple socialisation contexts; how, for example, certain forms of thinking processes are generating new learning mechanisms which teachers are still unaware of. We need further studies in cultural psychology and educational psychology in socioculturally diverse countries that will enable us to give more definitive answers to such questions.

\section{References}

Addleman, R. A., Nava, R. C., Cevallos, T., Brazo, C. J., \& Dixon, K. (2014). Preparing Teacher Candidates to Serve Students from Diverse Backgrounds: Triggering Transformative Learning through Short-Term Cultural Immersion. International Journal of Intercultural Relations, 43, 189-200. https://doi.org/10.1016/j.ijintrel.2014.08.005

Angelides, P. (2001). Using Critical Incidents to Understand School Cultures. Improving Schools, 4, 24-33. https://doi.org/10.1177/136548020100400105

Arthur, N. (2000). Using Critical Incidents to Investigate Cross-Cultural Transitions. 
Calgary, Canada: Department of Educational Psychology, The University of Calgary.

Arthur, N. (2001). Using Critical Incidents to Investigate Cross-Cultural Transitions. International Journal of Intercultural Relations, 25, 41-53.

Babel, A. (2014). The Role of Context in Interpreting Linguistic Variables. Boletín de Filología, 49, 49-85. https://doi.org/10.4067/S0718-93032014000200004

Barab, S., \& Squire, K. (2004). Design-Based Research: Putting a Stake in the Ground. The Journal of the Learning Sciences, 13, 1-14. https://doi.org/10.1207/s15327809jls1301_1

Bauer, C. (2015). Bolivia: Processes of Change. Bulletin of Latin American Research, 34, 388-389. https://doi.org/10.1111/blar.12332

Bernstein, B. (1994). La estructura del discurso pedagógico. Clases, códigos y control (Vol. IV). Madrid: Morata.

Berry, J. W. (2001). A Psychology of Immigration. Journal of Social Issues, 57, 615-631. https://doi.org/10.1111/0022-4537.00231

Brislin, R. W. (1986). Research Instruments. Field Methods in Cross-Cultural Research: Cross-Cultural Research and Methodology Series, 8, 137-164.

Bruner, J. S. (1991). Actos de significado. Madrid: Alianza.

Burgum, M., \& Bridge, C. (1997). Using Critical Incidents in Professional Education to Develop Skills of Reflection and Critical Thinking. In R. Pospisil, \& L. Willcoxson (Eds.), Learning through Teaching: Proceedings of the 6th Annual Teaching Learning Forum. Murdoch University.

Burnard, P. (2005). El uso del mapa de incidentes críticos y la narración para reflexionar sobre el aprendizaje musical. Revista Electrónica Complutense de Investigación en Educación Musical, 2, 1-15.

http://revistas.ucm.es/index.php/RECI/article/view/RECI0505110002A/8737

Carnoy, M., \& Levin, H. (1985). Schooling and Work in the Democratic State. Stanford, CA: Stanford University Press.

Castagno, A. E., \& Brayboy, B. M. J. (2008). Culturally Responsive Schooling for Indigenous Youth: A Review of the Literature. Review of Educational Research, 78, 941-993. https://doi.org/10.3102/0034654308323036

Centellas, M. (2015). Cycles of Reform: Placing Evo Morales's Bolivia. Latin American Research Review, 50, 229-241. https://doi.org/10.1353/lar.2015.0006

Cohen-Emerique, M. (1999). Análisis de incidentes críticos: Un modelo para la comunicación intercultural. Revista Antípodes, 145, 465-480.

Cohen-Emerique, M. (1999). Análisis de incidentes críticos: Un modelo para la comunicación intercultural. Revista Antípodes, 145, 465-480.

Corbin, J. M., \& Strauss, A. (1990). Grounded Theory Research: Procedures, Canons, and Evaluative Criteria. Qualitative Sociology, 13, 3-21.

Fontana, L. B. (2014). Indigenous Peasant “Otherness": Rural Identities and Political Processes in Bolivia. Bulletin of Latin American Research, 33, 436-451. https://doi.org/10.1111/blar.12207

Ford, K. (2009). Critical Incidents in the Experiences of Japanese Returnees. Language and Intercultural Communication, 9, 63-75. https://doi.org/10.1080/14708470902807701

Foucault, M. (1992). Microfísica del poder. Madrid: La Piqueta.

Freeland, J. (2003). Intercultural-Bilingual Education for an Interethnic-Plurilingual Society? The Case of Nicaragua's Caribbean Coast. Comparative Education, 39, 239-260. 
Geertz, C. (1983). Thick Description: Toward an Interpretive Theory of Culture. Long Grove, IL: Waveland Press.

Grosfoguel, R. (2005). The Implications of Subaltern Epistemologies for Global Capitalism: Transmodernity, Border Thinking and Global Coloniality. In W. Robinson, \& R. Applebaum (Eds.), Critical Globalization Studies (pp. 53-86). Londres: Routledge.

Grosfoguel, R. (2006). La descolonización de la economía política y los estudios poscoloniales. Tabula Rasa, 4, 19-46.

Haas, R. (2006). The Inability to Deal with (Inter-)Cultural Conflicts. Conclusions from Cultural Analysis. Psyche-Zeitschrift für Psychoanalyse und ihre Anwendungen, 60, 131-155.

Hornberger, N. H. (2014). Until I Became a Professional, I Was Not, Consciously, Indigenous: One Intercultural Bilingual Educator's Trajectory in Indigenous Language Revitalization. Journal of Language Identity and Education, 13, 283-299. https://doi.org/10.1080/15348458.2014.939028

Hornberger, N. H., \& Swinehart, K. F. (2012). Bilingual Intercultural Education and Andean Hip Hop: Transnational Sites for Indigenous Language and Identity. Language in Society, 41, 499-525. https://doi.org/10.1017/S0047404512000486

Ladegaard, H. J., \& Jenks, C. J. (2015). Language and Intercultural Communication in the Workplace: Critical Approaches to Theory and Practice. Language and Intercultural Communication, 15, 1-12. https://doi.org/10.1080/14708477.2014.985302

LeCompte, M. D., Preissle, J., \& Tesch, R. (1993). Ethnography and Qualitative Design in Educational Research. San Diego, CA: Academic Press.

Lopes Cardozo, M. T. A. (2012). Transforming Pre-Service Teacher Education in Bolivia: From Indigenous Denial to Decolonisation? Compare: A Journal of Comparative and International Education, 42, 751-772. https://doi.org/10.1080/03057925.2012.696040

Malpass, R. S., \& Salancik, G. R. (1977). Linear and Branching Formats in Culture Assimilator Training. International Journal of Intercultural Relations, 1, 76-87. https://doi.org/10.1016/0147-1767(77)90043-8

Maya-Jariego, I. (2010). Cinco factores en la adaptación psicológica de los inmigrantes. In Cruz-Zúñiga (Ed.), Sobre la convivencia intercultural y la construcción de espacios solidarios. La experiencia en Vera 2006-2008. Sevilla: ArCiBel Editores.

Mignolo, W. (2000). Diferencia Colonial y Razón Post Occidental. In S. Castro-Gómez (Ed.), La restructuración de las ciencias sociales en América Latina (pp. 3-28). Bogotá: Centro Editorial Javeriano.

Miles, M. B., \& Huberman, A. M. (1984). Qualitative Data Analysis. A Sourcebook of New Methods. Beverly Hills, CA: Sage Publications.

Mollis, M. (2003). Las Universidades en América Latina. Reformadas o Alteradas. La cosmética del poder financiero. Buenos Aires: CLACSO.

Monereo, C. (2010). La formación del profesorado: Una pauta para el análisis e intervención a través de incidentes críticos. Revista Iberoamericana de Educación, 52, 149-162.

Monereo, C., Badía, A., Bilbao, G., Cerrato, M., \& Weise, C. (2009). Ser un docente estratégico: Cuando cambiar la estrategia no basta. Cultura y Educación, 21, 237-256. https://doi.org/10.1174/113564009789052343

Muñoz Sedano, A. (2001). Enfoques y modelos de educación multicultural e intercultural. Encounters on Education, 1, 81-106.

Murakami, Y. (1985). Bullies in the Classroom. Japan Quarterly, 32, 407-411.

Navarro, R., López, A., \& Barroso, P. (1998). El análisis de incidentes críticos en la 
formación inicial de maestros. Revista Electrónica Interuniversitaria de Formación del Profesorado, 1, 11-25.

Ogbu, J. U. (1994). From Cultural Differences to Differences in Cultural Frame of Reference. In P. M. Greenfield, \& R. R. Cocking (Eds.), Cross-Cultural Roots of Minority Child Development (pp. 365-391). Hillsdale: LEA.

Quijano, A. (1999). La colonialidad del poder. Cultura y conocimiento en América Latina. In S. Castro-Gómez, O. Guariola-Rivera, \& C. Millan de Benavidez (Eds.), Pensar (en) los intersticios. Teoría y práctica de la crítica poscolonial (pp. 99-109). Santa Fé de Bogotá: Colección Pensar/Editorial Javeriana.

Ramos-Vidal, I. (2011). El análisis de incidentes críticos como método de estudio de los conflictos interculturales. Diversitas: Perspectivas en Psicología, 7, 143-159.

http://www.scielo.org.co/scielo.php?script=sci_arttext\&pid=S1794-99982011000100010 \&lng=en\&tlng=es https://doi.org/10.15332/s1794-9998.2011.0001.09

Snow, D. (2015). English Teaching, Intercultural Competence, and Criticalincident Exercises. Language and Intercultural Communication, 15, 285-299. https://doi.org/10.1080/14708477.2014.980746

Svampa, M. (2010). Movimientos sociales, matrices socio-políticas y nuevos contextos en América Latina. OneWorld Perspectives, Workings Papers 01, Kassel: Universität Kassel.

Svampa, M., \& Stefanoni, P. (2007). Entrevista a Álvaro García Linera: Evo simboliza el quiebre de un imaginario restringido a la subalternidad de los indígenas. In OSAL (VIII, 22). Buenos Aires: CLACSO.

Tapia, L. (2008). La reforma del sentido común en la dominación neoliberal y en la constitución de nuevos bloques históricos nacional-populares. In A. E. Ceceña (Coord.), De los saberes de la emancipación y de la dominación. Buenos Aires: Consejo Latinoamericano de Ciencias Sociales.

Telles, E., Flores, R. D., \& Urrea-Giraldo, F. (2015). Pigmentocracies: Educational Inequality, Skin Color and Census Ethnoracial Identification in Eight Latin American Countries. Research in Social Stratification and Mobility, 40, 39-58. https://doi.org/10.1016/j.rssm.2015.02.002

Vazques-Bronfman, A. (1996). Observar lo cotidiano, descubrir los valores detrás de las acciones del maestro. Cultura y Educación, 8, 17-24. https://doi.org/10.1174/113564096321273593

Vázquez Aguado, O. (2002). La competencia intercultural y las habilidades de intervención en mediación social intercultural. Portularia. Revista de Trabajo Social, 2, 125-138.

Weise, C. (2009). A questao indígena no mundo universitário boliviano: Uma história de muitas vozes, sentidos e realidades Crise da escola e políticas educativas (pp. 205-237). Belo Horizonte: Auténtica Editores.

Wenger, E. (2000). Communities of Practice and Social Learning Systems. Organization, 7, 225-246. 